\title{
Reply to Comment by M.F. Pereira, J.B. Silva and C. Gama on "Baltic provenance of top-Famennian siliciclastic material of the northern Rhenish Massif, Rhenohercynian zone of the Variscan orogen, by Koltonik et al., International Journal of Earth Sciences (2018) 107:2645-2669"
}

\author{
Katarzyna Kołtonik ${ }^{1,2}$ - Agnieszka Pisarzowska ${ }^{1,2}$ - Mariusz Paszkowski ${ }^{1}$. Jiří Sláma ${ }^{3}$. Ralph Thomas Becker ${ }^{4}$. \\ Marek Szczerba ${ }^{1}$. Wojciech Krawczyński ${ }^{2}$. Sven Hartenfels ${ }^{5}$ - Leszek Marynowski ${ }^{2}$ - Stanislaw Mazur ${ }^{1}$. \\ Wolfgang Franke ${ }^{6}$
}

Received: 11 February 2019 / Accepted: 21 February 2019 / Published online: 26 March 2019

(c) The Author(s) 2019

\section{Introduction}

We are grateful to M.F. Pereira and co-authors for their interest in our publication (Koltonik et al. 2018) and giving us a chance to look at it through the eyes of a reader. We are also thankful for the notification of some imperfections and shortcomings contained within our paper. We are, therefore, eager to briefly address the main points of criticism raised in the discussion article (Pereira et al. 2019).

Katarzyna Kołtonik

ndkolton@cyf-kr.edu.pl

1 Institute of Geological Sciences, Kraków Research Centre, Polish Academy of Sciences, Senacka 1, 31-002 Kraków, Poland

2 Faculty of Earth Sciences, University of Silesia, Będzińska 60, 41200 Sosnowiec, Poland

3 Institute of Geology, Czech Academy of Sciences, Rozvojová 269, 16500 Prague, Czech Republic

4 Institut für Geologie und Paläontologie, Westfälische Wilhelms-Universität, Corrensstrasse 24, 48149 Münster, Germany

5 Institut für Geologie und Mineralogie, Zülpicher Str. 49a, 50674 Cologne, Germany

6 Institut für Geowissenschaften der Goethe-Universität Frankfurt, Altenhöferallee 1, 60438 Frankfurt am Main, Germany

\section{Transregional correlations for the Variscan tectonic units}

The authors of the Comment suggest that our geological overview map of the European Variscides is incorrect in the section showing SW Iberia (our Fig. 1a). However, our paper reports results of the provenance study from the northern Rhenish Massif, and does not attempt to discuss the architecture and tectonic evolution of the Appalachian-Variscan belt. The aim of Fig. 1 is to locate the study area in the geological context of the European Variscides and not to extrapolate the implications of our findings down to southern Portugal. The map is mostly based on Franke (2014) that is explicitly stated in the caption. Our results are neutral towards the hypothetical correlation between the Mid-German Crystalline High and the southern domains of the Ossa-Morena Zone that is shown on the map. This issue remains beyond the scope of the study, since our samples were exclusively collected from the northern Variscan foreland. Nevertheless, the relationships shown on the map after Franke (2014; our Fig. 1a) are not necessarily wrong. Both the southern domains of the Ossa-Morena Zone (the Aracenas belt) and the Mid-German Crystalline High may have had Armoricantype basement that was simply eroded in the latter (Franke and Dulce 2017). Moreover, the quartzites with Mesoproterozoic detrital zircon grains (underplated, northerly derived shelf sediments) and Ordovician/Silurian orthogneisses may well be hidden at depth in south-western Portugal. 


\section{Detrital zircon signature of Avalonia}

Following classical papers by, e.g., Nance and Murphy (1994, 1996), Murphy et al. (2004) and Samson et al. (2005), we assume that a peri-Gondwanan provenance is indicated by abundant Neoproterozoic (Cadomian/Pan-African) zircon populations and a relative scarcity of Mesoproterozoic zircons. Since the analysed samples are practically devoid of Neoproterozoic grains and contain a wealth of Mesoproterozoic detrital zircons, we postulate a Baltica source for the Famennian (par)autochthonous sediments of the northern Rhenish Massif (Koltonik et al. 2018), in accord with Eckelmann et al. (2014) and earlier papers. In fact, the Upper Devonian sandstones in the Rhenohercynian zone wedge out towards the SE (Franke et al. 1978 and references therein) corroborating their northerly, Baltic derivation. Furthermore, K/Ar detrital muscovite ages by Huckriede et al. (2004) show the predominance of Scandian micas (c. $420 \mathrm{Ma}$ ) in those sandstones. Consequently, the existence of two source areas for the Rhenohercynian basin has been accepted in the past (e.g., Franke 2000; Huckriede et al. 2004). Sandstones represent clastic shelf and turbidites coming from the shelf margin in the northwest, whereas greywacke turbidites reveal derivation from the south east (e.g., Dallmeyer et al. 1995; Franke 2000). The immature, south east-derived greywacke turbidites record erosion of an active margin composed of Armorican basement and cover as well as later accreted sandstones of Baltoscandian derivation (Franke and Dulce 2017).

Detrital zircon age patterns fairly similar to those in (par) autochthonous sediments of the Rhenish Massif have been recognised in some units of the Pulo do Lobo Zone in SW Iberia (Braid et al. 2011; Pérez-Cáceres et al. 2017). In their Comment, Pereira et al. (2019) point out that these units could have been sourced from the oldest siliciclastic rocks of West Avalonia (early Neoproterozoic Gamble Brook Formation of Nova Scotia) having a comparable detrital zircon signature (Barr et al. 2003; Henderson et al. 2016). However, the Rhenish Massif is quite distant from Nova Scotia on the mid-Palaeozoic plate tectonic reconstructions (e.g., Keppie et al. 2003) and (par)autochthonous sediments of the Rhenohercynian zone contain detrital mica supplied by the Caledonian orogen (Huckriede et al. 2004). Furthermore, the early Neoproterozoic sedimentary rocks of Avalonian affinity have not yet been identified in NW Europe. At the end of Devonian, the Neoproterozoic Avalonian basement in the latter area was buried underneath Palaeozoic sediments (Franke and Dulce 2017; Franke et al. 2017), and it was not available as a source of detritus even if an early Neoproterozoic succession was somewhere hidden in the Variscan northern foreland. Of course, it is still possible that detritus of Famennian clastic rocks under the northern Rhenish Massif was supplied from a remote source in Nova Scotia, but, using Occam's razor, it is more realistic to assume their derivation from nearby Baltica (Kołtonik et al. 2018).

Another important issue is the presence of early Palaeozoic zircons (c. 500-400 Ma) in the analysed samples. Of course, potential sources of such zircons presently exist southward of the study area in the Mid-German Crystalline Rise and Northern Phyllite Zone as Silurian-Early Devonian metaigneous rocks and Ordovician metasediments, respectively. However, the Rhenohercynian Ocean was closed only in the Tournaisian (358-345 Ma, e.g., Franke et al. 2017) and, in the Famennian, the southern sources were still separated from the Rhenohercynian passive margin by a deep oceanic basin acting as a trap for southerly derived detritus (e.g., Franke and Dulce 2017). At the same time, clastic material laid down on the Rhenohercynian passive margin was supplied from the north (Fig. 1). In their summary of Caledonian magmatic and metamorphic events, Corfu et al. (2006) reported several potential sources for the early Palaeozoic detrital zircons ranging between c. 500 and $400 \mathrm{Ma}$ within Baltica that were available at the end of Devonian. In contrast, the present-day proximity of the Rhenohercynian autochthon and allochthon is a result of Carboniferous orogenic shortening and does not reflect Famennian paleogeography (Fig. 1). Consequently, the Caledonian source of detrital zircons from Famennian sediments of the Rhenish Massif seems to be more plausible (Koltonik et al. 2018). It is important to note that Laurussia had an active southern margin only during the Late Ordovician/Silurian to Siegenian, when the Rheic Ocean floor was subducted northwards creating a volvanic arc and accommodation space by back-arc spreading (Franke et al. 2017). After the opening of the Rhenohercynian Ocean (Lizard-Gießen-Harz) in the late Emsian, the southern margin of Laurussia was a passive margin (Franke et al. 2017), as shown in Fig. 1. This is indicated by the well-sorted nature of the shelf and shelf-derived clastic sediments (e.g., Franke and Dulce 2017) and by the intra-plate nature of basaltic volcanic rocks of Givetianto-Viséan age (alkali basalts in the Givetian/Frasnian and tholeiites afterwards; Floyd et al. 2000).

\section{Correlation of $\mathrm{U}-\mathrm{Pb}$ geochronological data}

Pereira et al. (2019) pointed out that U-Pb geochronological data from siliciclastic rocks of certain formations of the Pulo do Lobo Zone (Pereira et al. 2017; Pérez-Cáceres et al. 2017) are "virtually identical" to those from the Upper Devonian siliciclastic rocks of the Gießen and Hörre nappes, in the Lahn-Dill area (Rhenohercynian Zone; Eckelmann et al. 2014), suggesting derivation from comparable sources (Pereira et al. 2017). This is true, but only regards the Rhenohercynian allochthon (Gießen and Hörre nappes). On the other hand, the $\mathrm{U}-\mathrm{Pb}$ geochronological data from siliciclastic 


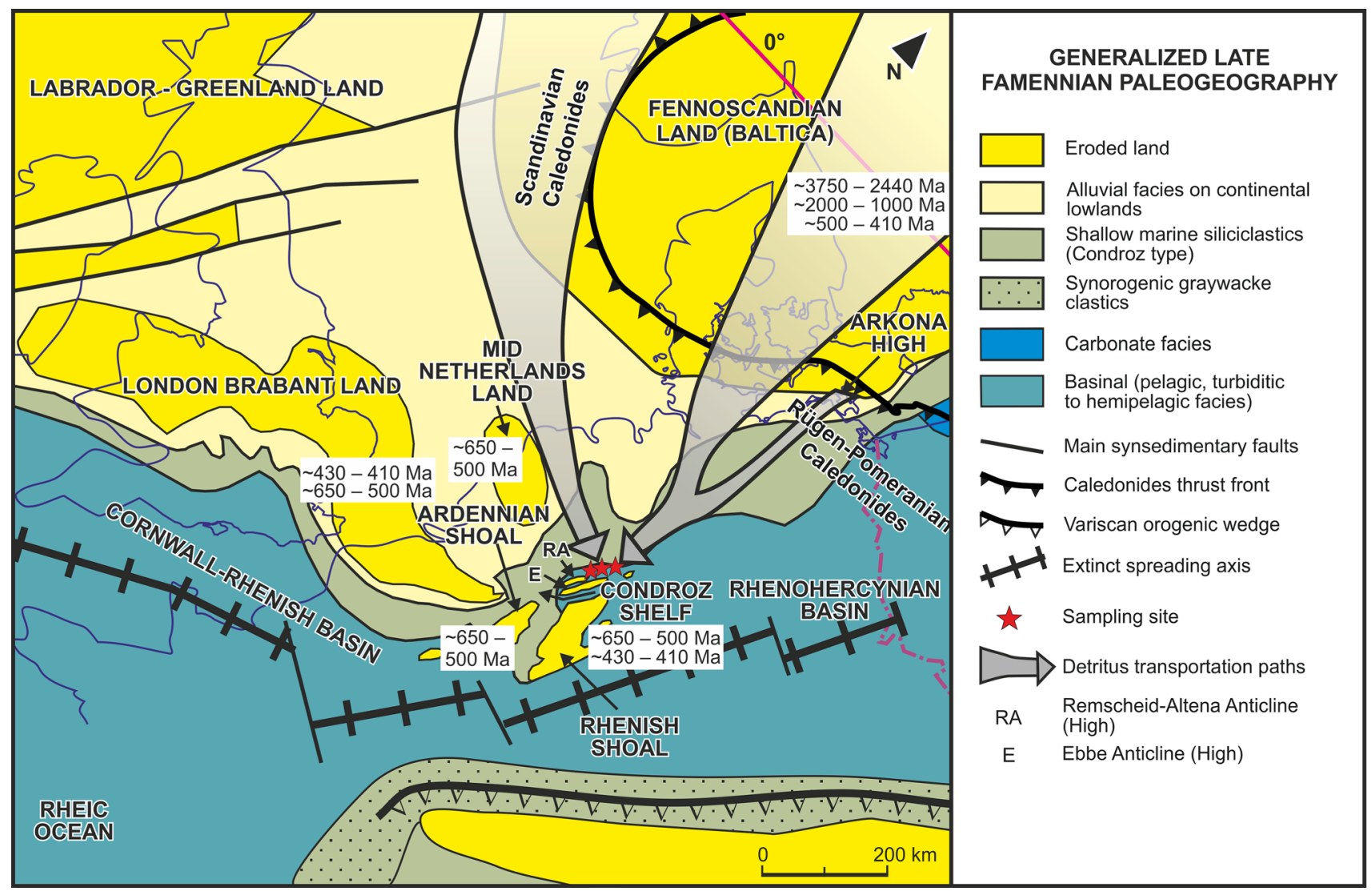

Fig. 1 Postulated detritus supply paths to the late Famennian clastic sediments of the northern Rhenish Massif. Palaeogeographic reconstruction after Paproth et al. (1986) and Franke et al. (2017), modified

rocks of the Rhenohercynian autochthon are very different (Eckelmann et al. 2014; Koltonik et al. 2018). There is no justification to extrapolate data from the allochthonous units as a proxy for the entire Rhenish Massif. The protolith of the Rhenohercynian allochthon was deposited on (1) the Rhenohercynian active margin next to the Mid-German Crystalline Rise, (2) oceanic crust of the Rhenohercynian Ocean, and (3) attenuated distal part of the Rhenohercynian passive margin (Franke 2000; Eckelmann et al. 2014; Franke et al. 2017). In contrast, a (par)autochthonous sedimentary cover was laid down on the margin of Avalonia (as part of Laurussia) that was docked to Baltica in the course of the Caledonian orogeny. Therefore, Baltica and Caledonian rocks were widely available as a source of detritus that was delivered from the north (Fig. 1) to the Famennian siliciclastic sediments in the present-day northern Rhenish Massif.

\section{Concluding remarks}

The majority of critical comments made by Pereira et al. (2019) are not fully consistent with the existing literature on the structure and evolution of the German
Rhenohercynian zone. The arguments presented do not challenge our work relying on the provenance analysis of detrital zircons from the Famennian (par)autochthonous sediments of the northern Rhenish Massif. We do not attempt to extrapolate the implications of our results to SW Iberia, a task that was clearly beyond the scope of our paper (Kołtonik et al. 2018). However, we would like to reiterate that the structure and evolution of the Rhenohercynian zone cannot be fully understood without the concept of the Rhenohercynian Ocean, whose opening and demise had a critical impact on shaping the geological relationships across the external part of the northern Variscides. In this context, the results obtained reinforce the idea that the external part of the Rhenohercynian basin was sourced from distinct foreland terranes located along the Variscan suture.

Acknowledgements We thank A. Łaptaś for assistance in the preparation of drawing. This study was supported by the Polish National Science Centre research Grant no. 2011/03/B/ST10/04602. Some work was supported by the Polish National Science Centre Grant nos. 2017/25/B/ST10/01348 and 2013/08/A/ST10/00717. 
Open Access This article is distributed under the terms of the Creative Commons Attribution 4.0 International License (http://creativeco mmons.org/licenses/by/4.0/), which permits unrestricted use, distribution, and reproduction in any medium, provided you give appropriate credit to the original author(s) and the source, provide a link to the Creative Commons license, and indicate if changes were made.

\section{References}

Barr SM, Davis DW, Kamo S, White CE (2003) Significance of U$\mathrm{Pb}$ detrital zircon ages in quartzite from peri-Gondwanan terranes, New Brunswick and Nova Scotia, Canada. Precambr Res 126(1-2):123-145

Braid JA, Murphy JB, Quesada C, Mortensen M (2011) Tectonic escape of a crustal fragment during the closure of the Rheic Ocean: U-Pb detrital zircon data from the Late Palaeozoic Pulo do Lobo and South Portuguese zones, southern Iberia. J Geol Soc Lond 168:383-392

Corfu F, Torsvik TH, Andersen TB, Ashwal LD, Ramsay DM, Roberts AJ (2006) Early Silurian mafic-ultramafic and granitic plutonism in contemporaneous flysch, Magerøy, northern Norway: U-Pb ages and regional significance. J Geol Soc Lond 163:291-301

Dallmeyer RD, Franke W, Weber K (1995) Pre-permian geology of Central and Eastern Europe. Springer, Berlin

Eckelmann K, Nesbor HD, Königshof P, Linnemann U, Hofmann M, Lange JM, Sagawe A (2014) Plate interactions of Laurussia and Gondwana during the formation of Pangaea-constraints from $\mathrm{U}-\mathrm{Pb}$ LA-SF-ICP-MS detrital zircon ages of Devonian and early Carboniferous siliciclastics of the Rhenohercynian zone, Central European Variscides. Gondwana Res 25:1484-1500

Floyd PA, Winchester JA, Seston R, Kryza R, Crowley QG (2000) Review of geochemical variation in lower Palaeozoic metabasites from the NE Bohemian Massif: intracratonic rifting and plumeridge interaction. In: Franke W, Haak V, Oncken O, Tanner D (eds) Orogenic processes: quantification and modelling in the Variscan belt, vol 179, no 1. Geological Society, Special Publications, London, pp 155-174

Franke W (2000) The mid-European segment of the Variscides: tectonostratigraphic units, terrane boundaries and plate tectonic evolution. In: Franke W, Haak V, Oncken O, Tanner D (eds) Orogenic processes: quantification and modelling in the Variscan belt, vol 179. Geological Society, Special Publications, London, pp 35-61

Franke W (2014) Topography of the Variscan orogen in Europe: failed not collapsed. Int J Earth Sci 103:1471-1499

Franke W, Dulce JC (2017) Back to sender: tectonic accretion and recycling of Baltica-derived Devonian clastic sediments in the Rheno-Hercynian Variscides. Int J Earth Sci 106:377-386

Franke W, Eder W, Engel W, Langenstrassen F (1978) Main aspects of geosynclinal sedimentation in the Rhenohercynian Zone. Zeitschrift der Deutschen Geologischen Gesellschaft 129(1):201-216
Franke W, Cocks LRM, Torsvik TH (2017) The Palaeozoic Variscan oceans revisited. Gondwana Res 48:257-284

Henderson BJ, Collins WJ, Murphy JB, Gutierrez-Alonso G, Hand G (2016) Gondwanan basement terranes of the Variscan-Appalachian orogen: Baltica, Saharan and West African hafnium isotopic fingerprints in Avalonia, Iberia and the Armorican Terranes. Tectonophysics 681:278-304

Huckriede H, Wemmer K, Ahrendt H (2004) Palaeogeography and tectonic structure of allochthonous units in the German part of the Rheno-Hercynian Belt (Central European Variscides). Int J Earth Sci 93(3):414-431

Keppie JD, Dostal J, Cameron KL, Solari LA, Ortega-Gutiérrez F, Lopez R (2003) Geochronology and geochemistry of Grenvillian igneous suites in the northern Oaxacan Complex, southern Mexico: tectonic implications. Precambr Res 120(3-4):365-389

Kołtonik K, Pisarzowska A, Paszkowski M, Sláma J, Becker RT, Szczerba M, Krawczyński W, Hartenfels S, Marynowski L (2018) Baltic provenance of top-Famennian siliciclastic material of the northern Rhenish Massif, Rhenohercynian zone of the Variscan orogen. Int J Earth Sci 107:2645-2669

Murphy JB, Fernández-Suárez J, Keppie JD, Jeffries TE (2004) Contiguous rather than discrete Paleozoic histories for the Avalon and Meguma terranes based on detrital zircon data. Geology 32(7):585-588

Nance RD, Murphy JB (1994) Contrasting basement isotopic signatures and the palinspastic restoration of peripheral orogens: example from the Neoproterozoic Avalonian-Cadomian belt. Geology 22(7):617-620

Nance RD, Murphy JB (1996) Basement isotopic signatures and Neoproterozoic paleogeography of Avalonian-Cadomian and related terranes in the circum-North Atlantic. In: Special Papers-Geological Society of America, pp 333-346

Paproth E, Dreesen R, Thorez J (1986) Famennian paleogeography and event stratigraphy of northwestern Europe. Annales de la Société géologique de Belgique 109:175-186

Pereira MF, Gutierrez-Alonso G, Murphy JB, Drost K, Gama C, Silva JB (2017) Birth and demise of the Rheic Ocean magmatic arc(s): combined $\mathrm{U}-\mathrm{Pb}$ and $\mathrm{Hf}$ isotope analyses in detrital zircon from SW Iberia siliciclastic strata. Lithos 278-281:383-399

Pereira MF, Silva JB, Gama C (2019) Comment on Baltic provenance of top-Famennian siliciclastic material of the northern Rhenish Massif, Rhenohercynian zone of the Variscan orogen, by Koltonik et al., International Journal of Earth Sciences (2018) 107:26452669. Int J Earth Sci. https://doi.org/10.1007/s00531-019-01691 -0 (this issue)

Pérez-Cáceres I, Poyatos DM, Simancas JF, Azor A (2017) Testing the Avalonian affinity of the South Portuguese Zone and the Neoproterozoic evolution of SW Iberia through detrital zircon populations. Gondwana Res 42:177-192

Samson SD, D'Lemos RS, Miller BV, Hamilton MA (2005) Neoproterozoic palaeogeography of the Cadomia and Avalon terranes: constraints from detrital zircon U-Pb ages. J Geol Soc 162(1):65-71 